\title{
Notes on the Translations and Acculturations
}

\author{
Dragos Calma \\ University College Dublin / Newman Centre for the Study of Religions, \\ Dublin
}

This is the second of three volumes publishing the proceedings of the Parisian conference dedicated to the reception of the Elements of Theology and the Book of Causes. This meeting was dedicated mostly to the translations and various forms of acculturations of these two works in Byzantium, the Caucasus, the lands of Islam, the Latin West and the Jewish Western communities. I organised it in collaboration with the much-regretted Marc Geoffroy on 12-13 February 2016, within the framework of the project LIBER (ANR-13-PDOCoo18-01). The preparation for publication took a long time indeed, and its last stages were accomplished within the framework of a larger ERC project (NeoplAT_ERC_CoG_771640).

First and foremost, I wish to thank all the collaborators for their patience and their understanding during these years. I renew my gratitude toward the funding bodies that supported the organisation of these meetings: École pratique des hautes études, Équipe "Philosophie arabe" of the Centre "Jean Pépin"CNRS (UMR 8230), Laboratoire d'études sur les monothéismes-CNRS (UMR 8584), Labex haStec (Laboratoire européen d'histoire et anthropologie des savoirs, des techniques et des croyances), Institut de recherche et d'histoire des textes—CNRS, Centre "Pierre Abélard"—Université Paris Sorbonne. Equally, I wish to thank again Evan King and Liz Curry for their help in preparing this volume, Robert M. Berchman and John F. Finamore for accepting the publication of these volumes in their series; Jennifer Pavelko for her support; and the peer-reviewers for their effort and comments.

As for the first volume, minor rearrangements (compared to the original program) seemed necessary in order to strengthen the thematic coherence of the volume. Hence, Michael Chase's and Pascale Bermon's papers were delivered during the third meeting but are published in this volume, whereas Carlos Steel's paper will be published in the third volume. I am happy to welcome contributors invited to collaborate for this volume: Victoria Arroche, Anna Gioffreda, Sokrates-Athanasios Kiosoglou and Michele Trizio.

A summary of each section will provide more clarity. 
Frederick Lauritzen describes the multiple references to Proclus in Byzantium, such as the 6th-century anecdotical (and historically inaccurate) military advice allegedly provided to the emperor Anastasius, or the 1oth-century remarks describing him as a plagiarist of Dionysius ps.-Areopagite. More interestingly, some of Maximus the Confessor's language echoes Proclus', notably when describing the immoveable and incorporeal realm of the divine. Lauritzen equally gives a list of correspondences between the works of Michael Psellos (published under the title Philosophica Minora) and Proclus' Elements of Theology. In the 14th century, Gregory Palamas, accused of being a Platonist by one of his adversaries, equally refers explicitly to Proclus (in Contra Acyndinum). Lauritzen even argues that the contemplation of the divine energies described by Palamas have echoes of the Elements of Theology, and stresses the continuity between Proclus, Maximus the Confessor, Michael Psellos and Gregory Palamas.

Lauritzen advocates that Pagan philosophy was studied in Byzantium "by a variety of thinkers rather than isolated circles of intellectuals" (p. 29). Proclus' Elements of Theology would be an example of this widespread influence, and Nicholas of Methone's critique attests to the presence of a veritable trend in the 12 th century.

Stephen Gersh studies the influence of Proclus' Elements of Theology on Eustratios' theory of universals in the Commentary on the Nicomachean Ethics and in the Commentary on the Posterior Analytics. Gersh identifies incongruities between the ways Eustratios presents the universals in these two texts, with the latter text introducing the idea that the universal before the parts is not the Platonic transcendent form (like in the Commentary on the Ethics), but rather recalls an "originative monad or an unparticipated term" (p. 37). As a consequence, the two other universals (of parts and in the parts) have slightly different definitions inasmuch as the concepts of parts and whole are redefined relative to this principle: the "whole of parts" is the entire collection of monads proceeding from the originative monad, and the "whole in parts" is each individual monad within this collection.

Gersh identifies the sources in Proclus' Elements of Theology and the two prologues of the Commentary on the First Book of Euclid's Elements. Indeed, in prop. 67 of the Elements of Theology, Proclus presents the same tripartite distinction (before the parts, of parts, in the part), although not explicitly in

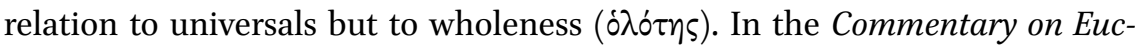
lid's Elements, Proclus explicitly discusses a threefold division of universals, in 
somewhat similar terms. Gersh shows that Eustratios does not simply combine these analogous theories, inasmuch as, for example, the whole of the parts does not correspond to any of the three universals, but more to a relation (that of genus and species). For Eustratios, mathematical and dialectical notions are inextricably linked. Gersh contributes to the debate on the status of universals in Eustratios (and Proclus) by underlying the role of cognitive faculties (intellection, discursive reason and opinion) in grasping the universal. He equally provides a close examination of the meaning of the word logos in Proclus' Commentary on Euclid, concluding that even the Elements of Theology "consists of propositions and proofs which exemplify the sense of logos as a combination of thinking + the one and the many in syllogistic argument" (p. 47). Eustratios' flexible use of logos seems, at times, similar to the Hellenic Neoplatonic tradition, but at other times more closely related to Christian Platonism.

Joshua M. Robinson focuses on Psellos' understanding of Proclus' metaphysics (mainly his views on emanation and on the unity of the One) in respect to the Christian teachings on creation and Trinity. He does not exclude the possibility that Nicholas of Methone wrote his Refutation as a reaction to Psellos' abundant use of Proclus. Robinson argues, contrary to Lauritzen, Gioffreda and Trizio, that there is no direct evidence for any substantial interest in Proclus in the 12th century (with the exception of Ioane Petritsi). The comparisons between the positions of Psellos and Nicholas are illuminating.

Robinson notes that one should not exaggerate the weight of Proclus in Psellos (comprising both abundant compilation of citations and very specific explanations) and mentions, for instance, that the number of references to Aristotle and Plotinus exceed the number of references to Proclus. In some cases, Proclus is simply the foremost representative of Hellenic thought and stands for Pagan wisdom as such. One should not conclude that by citing Proclus, Psellos intends to endorse all the views he reports, although in some cases he finds astonishing degrees of compatibility with the Trinitarian dogma (e.g. in prop. 35 of the Elements) or the Incarnation (e.g. in a quotation from De sacrificio et magica). There are cases where Psellos intentionally modifies Proclus' argument in order to render it compatible with Trinitarian doctrine: when dealing with prop. 7 , he omits that, according to Proclus, within the hierarchy of gods, one cannot produce another equal to itself.

For Psellos, as Robinson points out, reason ( $\lambda{ }^{\circ} \gamma \circ \varsigma$ ) is equally important for Greeks (i.e. the Pagan Hellenic tradition) and Christians, yet the truth is rooted in revelation and tradition. By contrast, Nicholas "regards Proclus' entire project as a presumptuous rationalism aiming to scale the heavens (like the Tower of Babel) by the power of human thought" (p. 63). Robinson's careful examin- 
ation of citations leads him to the conclusion that, contrary to a rather widely shared view among scholars, there are not that many occasions where Psellos agrees with Proclus, and "in some passages [he is] clearly conscious that philosophy can lead into heresy” (p. 89).

Anna Gioffreda and Michele Trizio revisit the question of the authenticity of Methone's Refutation of Proclus' Elements of Theology: two 14th-century manuscripts attribute chapters 139 and 146 of the work to Procopius of Gaza (ca 465/ $470-526 / 530$ ). Indeed, there is a scholarly debate about the paternity of these fragments that has been recently revived by E. Amato (2010, 2014). In 2012, the same fragments have been ascribed to Ps-Procopius by I. Polemis in his edition of treatises attributed to the 14th-century author Isaak Argyros.

Gioffreda and Trizio refute Amato's arguments stating, as Lauritzen has in his contribution, that Proclus' Elements of Theology was widely known and read by 11th- and 12th-century Byzantine scholars. They equally recall the numerous internal evidence pleading in favour of a middle Byzantine dating. Among the external evidence, they mention the explicit references by Photios to Procopius' works (and Psellos' remarks that are borrowed from these), and a scholion to Lucian's Philopseudes in relation to Procopius' Refutation of Proclus' Commentary on the Chaldean Oracles.

Gioffreda and Trizio support Stiglmayr's arguments against the Procopian paternity of the chapters 139 and 146 by mentioning the anti-Filioquist reasoning on the generation of the Son and the spiration of the Spirit, based on a Byzantine tradition citing Gregory of Nazianzus. They equally show that the topics discussed in the above mentioned chapters echo theological themes discussed by Nicholas elsewhere.

Their palaeographical examination adds further important elements: chapters 139 and 146 have been copied more than once (and with differences!) in Vat. gr. 1096 and Vat. gr. 604 by one and the same person: Isaak Argyros. These two manuscripts, and others, are linked with anti-Palamite circles. The two chapters appear in Argyros' hand in his own Adversus Cantacuzenum, a work that makes use of numerous Patristic quotations, and in a florilegium that he prepared for subsequent anti-Palamite treatises. The attributions of these chapters to Procopius are in Argyros' hand, and they both serve the purpose of the polemic, by providing arguments against the distinction between God's essence and his providential energies. The attributions to Procopius, therefore, attest to a 14th-century polemic about God's unity and the orthodox understanding of creation, and "in absence of new incontrovertible evidence, this attribution must be regarded as highly dubious" (p. 129). 
Tengiz Iremadze discusses the broader context of the reception of Proclus and Neoplatonism in Caucasian philosophy. With its origins in the Byzantine tradition, the Caucasian tradition of philosophy grew into an independent tradition of thought, equally influenced by other philosophical traditions. However, within this Caucasian tradition, Proclus' Elements of Theology played an important role.

Ioane Petritsi's famously translated into Georgian and commented on the Elements of Theology, but one has to recall that he also translated the works of Nemesius of Emesa. Summarizing Petritsi's commentary and explaining his intellectual project, Iremadze insists on the pedagogical role the Georgian commentator gave to the Elements: the ultimate goal of Proclus' work, according to Petritsi, was to train one's intellect in the knowledge of the One in a systematic and syllogistic manner. Iremadze's hypothesis is worth considering: Petritsi's commentary is often like a dialogue with the reader, probably echoing his discussions with the community of monks (or rather novices) of the Gelati monastery. Highly considering Plato and the entire Platonic tradition, Petritsi does seem to be influenced by the Aristotelian heritage.

Ioane Petritsi's translation and commentary on Proclus is relatively familiar to scholars, yet a wider scholarly interaction with the Armenian tradition (including commentaries and translations) is still yet to be considered. Iremadze mentions some of them, such as the translation of the Elements into Armenian in 1248 or the 1651 commentary in Armenian on the Elements by Svimeon Dshughaezi, which was translated into Georgian in 1757. In the 18th century, there were at least two commentaries on the Elements accessible in Georgian.

Iremadze equally mentions other major figures that made a decisive contribution to the assimilation of Proclean thought into Georgian, although not through running commentaries. Sulchan-Saba Orbeliani (1658-1726), a diplomat, integrated propositions and references to Proclus in his Georgian Dictionary (an encyclopaedia and dictionary). Anton I of Georgia (1720-1788), Patriarch of the Orthodox Georgian Church, cited explicitly and commented upon Petritsi's commentary and Proclus in his work Spekali. Joane Bagrationi (17681830) mainly relied on the Armenian commentaries on Proclus in his main work, Kalmasoba, written in a Platonic dialogue form, where he explains 86 of the 211 propositions of the Elements. Iremadze concludes that "die kaukasischen Philosophen nutzten daher gern seine [i.e. Proklos] Lehre bei der Bestimmung der Aufgabe der Philosophie und ihres Wesens" (p. 150). 
Michael Chase studies the sources and origins of the Theology of Aristotle, and sheds new light on the first reception of Hellenic Neoplatonic thinking in 9th-century Baghdad in the circle of al-Kindī, where the Book of Causes originated. Chase reopens the file regarding the attribution of a commentary on the Enneads to Porphyry, which might have been translated into Arabic, and which was used to compose the Theology of Aristotle under the supervision of al-Kindī. Augustine in the West or Gregory of Nyssa in the East knew Plotinus' Enneads through Porphyry's exegesis, which consists of three elements: headings (abbreviations of contents), summaries of arguments and commentaries. Chase argues that not only the headings $(\varkappa \varepsilon \varphi \dot{\alpha} \lambda \alpha i \alpha)$ and the summaries $(\dot{\varepsilon} \pi \mathrm{l}-$ $\chi \varepsilon 1 p \eta \mu \alpha \tau \alpha)$ were translated into Arabic and used in the Theology of Aristotle, as the recent work by C. D'Ancona has proved, but also the commentaries (i $\pi 0-$ $\mu \nu \dot{\eta} \mu \alpha \tau \alpha)$, which are otherwise lost.

Leaving behind other scholarly exegesis, Chase studies some of the main themes of the Theology of Aristotle, such as the identification of the First Principle with pure being, the "typical confusion" of soul and intellect, the learned ignorance, divine knowledge and providence, instantaneous creation and the doctrine of action "by being alone". Chase shows that all these doctrines were defended by Porphyry, and that even though some of his works are lost, other authors (e.g. Philoponus) ascribed these doctrines to him. In light of this evidence, there is no need, argues Chase, to postulate that the Theology of Aristotle was influenced by Dionysius the ps.-Areopagite. An intermediary cannot be fully excluded, but it is more "economical" to postulate the influence of only one author, i.e. Porphyry, notably because in the first paragraph of the Theology of Aristotle he is explicitly mentioned as the main source. However, it must be noted that Chase does not claim that the Theology is a translation into Arabic of Porphyry's lost commentary on the Enneads, inasmuch as he does not deny the possibility of various interventions of the adaptor or editor, al-Kindī. But the Porphyrian origin of the Theology of Aristotle should be reconsidered more carefully.

Peter Adamson endorses F. Zimmermann's hypothesis that the Theology of Aristotle, a "partial Arabic translation of the last three Enneads" (p. 182), together with other major translations from Greek—notably Proclus' Elements of Theology and writings of Alexander of Aphrodisias-, all produced within the circle of al-Kindī, circulated in a "metaphysics file" with a preface deliberately attributing them to Aristotle. In the Harmony of the Two Sages there are allusions to propositions 1 to 5 (possibly even prop. 25) of the Elements of Theo- 
logy. Thus, as Adamson points out, al-Fārābī's main difficulty is not to explain the harmony between Plato and Aristotle, but the harmony between Aristotle (of the Metaphysics) and Aristotle (of the Theology).

In a short section of the Harmony devoted to the question of the creation of the universe, al-Fārābī shows that he is aware that a temporal beginning of the universe is denied in On the Heavens. As a counterargument, he cites a fragment from the Theology of Aristotle clearly dependent on the Arabic Proclus. The harmony is explained through a complex set of arguments based on the identity between Aristotle's First Mover and the One as pure being, exercising a specific type of causality ("without time", hence in accordance with On the Heavens), as creator of all things (a trademark of al-Kindī and his circle).

Another section of the Harmony discusses the theory of Forms, on which Aristotle notoriously criticised Plato. Yet, as Adamson shows, if "on Aristotle's interpretation the Platonic theory makes Forms the objects of knowledge", "the Harmony is saying that there will actually be a science or knowledge that is itself a Form", which the author of the Harmony dismisses as ridiculous (p. 193-194). The contradiction between the Aristotle of the Metaphysics and the Aristotle of the Theology is solved by al-Fārābi through a digression on divine knowledge stating that, by an extended meaning of words (e.g. by applying synonymous language to nobler realities), one can say that God "knew" the Forms of things he created. This would enable to preserve within the Kindian conceptual framework the understanding of the Aristotelian First Mover as "maker". In both cases examined, Adamson notes that Plato is assimilated to Aristotle, not vice-versa.

Elvira Wakelnig discusses the origins of the Book of Causes by examining the 1oth-century work, Al-Fușül fì l-ma'ālim al-ilāhìya by Abū l-Hasan Muhammad ibn Yüsuf al-Āmirì. Wakelnig compares it with the version of the Book of Causes translated into Latin, and shows that themes and concepts from the first nine chapters of the Book of Causes and from chapters 11(?), 12, 16, 18-26, 29-30, 31(?) are tacitly borrowed by al-Āmirī. Wakelnig equally indicates that al-Āmirī's Al-Fușul bares similarities with the 16th chapter of a different version of the Book of Causes (= Book of Causes II), preserved only in Arabic and edited in 2002 by S. Oudaimah and P. Thillet. Wakelnig also identifies significant differences between these two texts, differences that could come from the fact that al-Āmirī had access to a "Proto-Liber de causis", that was earlier than the two versions currently known (the Book of Causes translated into Latin and the Book of Causes II). And it is this "Proto-Liber de causis" that al-Kindī might have composed. Wakelnig compares the same Al-Fușül with a text entitled Kitāb al- 
haraka (Book of Motion), a compilation of extracts from the Arabic translations of Proclus' Elements of Theology and Elements of Physics. Some of the propositions translated from the Elements of Theology are preserved only in this Kitāb al-haraka, which, as Wakelnig argues, was most probably composed before the Liber de causis II.

Wakelnig concludes that this Proto-Liber de causis might be the source for the four texts examined: the Book of Causes translated into Latin, the Book of Causes II, the Kitāb al-ḥaraka and al-'Āmirī's Al-Fuṣūl.

Richard Taylor notes that in the Middle Ages the Book of Causes was ascribed to Aristotle, while modern scholarship often considers it as no more than an abbreviated version of Proclus' Elements of Theology. In his contribution, Taylor intends to reassess this received view (originating in Aquinas' commentary) and focuses mostly on propositions and themes present in the Arabic De causis, but absent in Proclus. He examines mostly, but not exclusively, the chapters 5, 8 and 21, and identifies similarities with the Theology of Aristotle, Sayings of the Greek Wiseman and the ps.-Farabian Letter on Divine Intellect, which are all dependent, to various degrees, on Plotinus' Enneads. However, as Taylor notes, the idea of a creator or Pure Good as transcendent creative knowledge, present in the chapter 8 of the Theology of Aristotle, is rejected by Plotinus in relation to the One and relegated to the level of Nous. In the Plotiniana Arabica there is certain Aristotelian reminiscence of a self-thinking First Mover.

In order to maintain coherence with this teaching from the Plotiniana Arabica, the author of the Arabic Book of Causes deliberately modifies the themes from the Proclean propositions 11 and 123 in order to introduce, in chapter 5 , the doctrine of the illuminating light shed on the inferior intelligence by the First Cause. Taylor considers that "the source" of this theme is found in the Sayings of the Greek Wiseman, depending on Plotinus' Enneads v 6,4.14-22. The theme in chapter 21 of the First Cause as perfect, self-sufficient and beyond language is similar to the 1oth book of the Theology of Aristotle, dependent on Enneads $\mathrm{V} 2,1$. The rationale underpinning these transformations and the preference for certain themes, such as the idea of a pure being creator of all things, consists in al-Kindi's agenda to present "philosophy as a companion to the religious teachings of Islam" (p. 225). Taylor emphasizes the importance of connecting the metaphysics of the Book of Causes to al-Kindi's intellectual program as a way to revise, on more accurate and solid grounds, received views about the weight and role of the Elements of the Theology. The Book of Causes is the expression of a "new form of Aristotelianism developed through a transformed understanding of texts from Plotinus" (p. 228). 
Jamal Rachak dedicates a contribution to Ibn Bāğğa (Avempace). Firstly, Rachak shows that in Ibn Bāğğa's works of undisputed authority, only Aristotle, Plato, Galen, Alexander of Aphrodisias, Themistius, Philoponus, Al-Fārābī and Al-Ġazālī are explicitly cited. He endorses Endress' argument that Ibn Bāğğa uses, unwittingly, the Proclean concept of the hierarchy of "spiritual forms" (from the Elements of Theology, prop. 15-17) based on a work falsely attributed to Alexander of Aphrodisias. Rachak identifies a certain number of Neoplatonic themes in Ibn Bāğğa's texts before discussing a series of letters, or rather thirteen fragments, preserved only in one manuscript (in Oxford, Bodley Pococke 206), which transmit works by his friend and disciple, Ibn al-Imām.

There is a dispute about the authenticity of these fragments. Some scholars—-such as the editor of these fragments, Ğ. al-'Alawī—argued against Ibn Băğğg's authorship, while others-such as M.I. Fayyūmī-argued in favour of their authenticity. Rachak has argued elsewhere that these fragments echo a correspondence between Ibn Băğğa and Ibn al-Imām, the texts preserved in Oxford being written by the latter. If this hypothesis is accepted, the fragments acquire a major historical significance since they would be among the first texts in the lands of Islam explicitly naming propositions of the Book of Causes. Moreover, for the author of these letters, the Book of Causes has the same authority as al-Fārābī, al-Ġazālī and the Qửan.

On the basis of manuscript evidence and stylistic comparisons, Dag Nikolaus Hasse provides a complex analysis of the translations (from Arabic into Latin) of al-Kindī's On the Intellect, al-Fārābī's Enumeration of the Sciences, Isaac Israeli's On Definitions and Descriptions and the Book of Causes. Although scholars have taken it for granted that Gundisalvi translated the first three works, none of the manuscripts consulted by Hasse mentions him explicitly. By comparison, at least five manuscripts and the well-known list of translations by Gerard of Cremona's socii mention him explicitly in relation with all these texts.

Gerard of Cremona and Dominicus Gundisalvi were contemporaries, both were active in Toledo and served as canons of its cathedral. There is some scholarly debate over the chronology of their translations (assuming that Gundisalvi is indeed the translator). Using specially designed software, Hasse then compared Gerard's eight other translations and the seven other translations by Gundisalvi, and then compared these results with the four previously mentioned works. Hasse's philological and statistical analysis suggests that: in the case of Isaac Israeli, On Definitions, Gerard's version was prior to the other 
translation (or Gundisalvi's revision). Al-Fārābī's Enumeration of the Sciences was first translated by Gerard, then Gundisalvi "revised the translation by thoroughly rewriting some passages", while leaving numerous other passages untouched (p. 265). It is "highly probable" that Gerard was the (first) translator of al-Kindi's On the Intellect, as is suggested by some characteristic translations (e.g. cadere sub is typical for Gerard, whereas Gundisalvi prefers subicere).

The examination of Pattin's Liber de causis is, to my mind, less decisive given that the current state of the "edition" and the lack of a rich critical apparatus do not allow such a subtle and nuanced philological analysis. However, Hasse's approach is instructive and it must be included in any upcoming study or edition. His conclusion must also be retained: the current edition of De causis has a distinctive "Gerardian sound", and it is "very unlikely that Gundisalvi revised the Liber de causis" (p. 272).

Jules Janssens discusses the same topic of the "double translation", but his research and methodology is different from the one provided by Hasse. Moreover, Janssens has a slightly different understanding of the syntagma "double translation", in that it does not apply to two largely different or almost new translations of the same text (like in the cases of the works studies by Hasse), but rather to minimal and limited variations made with the aim of providing a more fluent, "Latinised" version of a first, more literal attempt. Janssens' hypothesis, based on his previous work on the manuscripts of Avicenna latinus, is that the variants of such a "double translation" (made either by the first translator or by a copyist) were present in the same, original manuscript.

Janssens discusses several cases, but I mention here only two of them: one is the expression non destruuntur nec permutantur in chap. $\mathrm{x}(\mathrm{XI})$ of the Book of Causes, prop. 101, 1. 55-56. Endorsing Vansteenkiste's hypothesis that permutantur perfectly renders the Arabic tastahilu, Janssens argues that the translator firstly chose non destruuntur and then he opted for permutantur in order to provide a more accurate translation. Indeed, some manuscripts have non destruuntur vel permutantur, with vel indicating in fact an alternative solution for the Latin translation and not a complementary explanation in the original. From the critical apparatus provided by Pattin, one concludes that a branch of the manuscript tradition transmitted the two variants and another branch only the first variant (destruuntur), but none of the manuscripts seem to transmit only the second, more accurate, variant (permutantur). It may be worth discussing, taking a similar approach, the case of non patitur neque destruitur, from II, 21, l. 78-79.

Another interesting example is the expression apponitur vel parificatur proposed by Pattin in II, 25, 1. 91. Janssens notes that numerous manuscripts 
have opponitur, and that a copyist probably decided to modify it to apponitur in order to provide more coherence with parificatur. Janssens suggests that

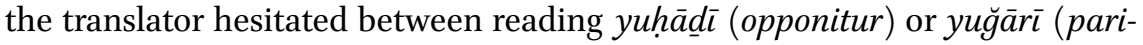
ficatur): without diacritical points, the similar orthographies of these verbs can generate confusion.

Janssens strongly emphasizes the importance of producing a solid critical edition of the Arabic text (and the search for new Arabic manuscripts as the basis for it) and a new, better Latin edition. The latter should mirror, on the one hand, the Arabic archetype and, on the other hand, its diverse transmission in the Latin West.

Pascale Bermon addresses a question that, since the publication of the edition of Thomas Aquinas' commentary on the Book of Causes in 1954, has been overlooked by scholars: what is precisely the text that he knew and commented upon?

This question might have seemed redundant inasmuch as everyone read in the introduction (originally published in 1954 and preserved in the "new revised edition" from 2002): "J' ai imprimé un texte du Liber de causis qui suit celui de Bardenhewer sauf chaque fois que saint Thomas, citant le Liber, présente un autre texte. J'ai soigneusement noté dans l'apparat critique à l'endroit de ces citations les divergences. Autrement dit, je me suis appliqué à reconstituer, chaque fois que c'est possible, le manuscrit que saint Thomas avait sous les yeux" (Introduction to Thomas d'Aquinas, Expositio super Librum de causis, Paris, Vrin, 2002 p. LXXIII). In reality, the edition from 2002 is nothing but a re-impression of the 1954 edition. The expression "new revised edition" is regrettably inaccurate and misleading. Scholars should remember that in the "new edition" of Aquinas' commentary they will not find Pattin's text (not even in the bibliography!) and more generally nothing that has been published on the topic since 1954. And with Bermon's article, one realizes that even the Latin edition does not respect its philological promises.

Carefully analysing Aquinas' exegesis of the propositions with the famous Arabic transliterations alachili / achili and yliathim, Bermon notes (p. 329-331, $33^{2}, 334$ ) several cases where Saffrey does not indicate the differences between the text commented by Aquinas and the edition published by Bardenhewer. The first conclusion is obvious: the Latin text of the Book of Causes that one reads in Saffrey's edition is not what Aquinas had in front of his eyes. Bermon reconstructs parts of the text that Aquinas might have known and concludes that he read a version of the Book of Causes without the transliteration alachili I achili. But Aquinas knew and explained the term yliathim (form), which he connects with hylè (matter), most probably influenced by the fake etymology 
proposed by Albert the Great. The Arabic original, hilya, derives from the ProtoLiber de causis, as E. Wakelnig argues in her study, and is borrowed from the Arabic translation of the Enneads.

Alessandra Beccarisi argues that Eckhart prefers Liber de causis to Proclus, and, unlike Dietrich of Freiberg, cites them together only five times. Although overlooked by scholarship, proposition XV is the most cited by Eckhart and has, according to Beccarisi, a pivotal role in his thought. Beccarisi identifies and discusses three main themes where Eckhart uses this proposition: in relation to the concept of self-identity of the One (negatio negationis); in relation with the terms istic and Isticheit; with reference to the metaphysics of the intellect (self-determination).

Beccarisi argues that there is no distinction between Eckhart's German and Latin works in respect to his understanding of the One (as if it were transcendently beyond Being in the German texts and ontological-transcendental in the Latin texts). Beccarisi shows that "the One is [...] the highest negation, because it is the Being without negations, or rather Being itself" (p. 357). Eckhart builds his interpretation of the Neoplatonic One upon the divine selfrevelation of Exodus (ego sum qui sum). Understood as a manifestation of God's self-reflexivity, a returning to His own self, it is in accordance with the reditio completa of the prop. XV of the Book of Causes. In his German sermons, Eckhart expresses the same idea through the terms istic and Isticheit. Analysing the theory of self-determination, Beccarisi refers once more to the German sermons and argues that the expression inwert würkende stands for the Latin reflexio, and expresses the capacity of the intellect to "work inwardly". Pursuing the same careful philological and speculative analysis, Beccarisi endorses Markus Vinzent's hypothesis that Eckhart himself translated some fragments of his commentary on the Book of Wisdom from Latin into German, and that an overlooked citation and interpretation of prop. XVII of the Book of Causes is complementary proof of this. One of Beccarisi's final conclusions is that "Proclus had (...) an importance certainly inferior to that which some scholars have attributed to him" (p. 371).

Victoria Arroche considers that Dante used the Liber de causis to develop his political theories in the Monarchia and Convivio. According to Arroche, two concepts are crucial in this regard: potentia (or rather ultima potentia) and virtus, inasmuch as they denote power and strength, but are also the same words used to describe the flowing from the first causes through the secondary causes until the lowest levels of reality. This blending of metaphysical and political concepts represents for Arroche one of the main characteristics of 
Dante's political thought. In some significant paragraphs of the Monarchia and the Convivio, Dante uses ultimum de potentia or potenza ultima in respect to the intellectual virtue of the human being.

As Arroche notes, in the Liber de causis one equally reads the same syntagma: intelligentia, completa et ultima in potentia et reliquis bonitatibus (IV.43). Intellectual activity is not only the ultimate goal of each individual, but also the ultimate goal of the human race. And politics, as the "specific relation between the community and the Monarch [...] stems from the exercise of that intellectual capacity" (p. 383).

Arroche indicates that two more concepts are equally important in understanding Dante's political view: ordinatio and reductio. For the latter, Arroche argues that this concept establishes the monarch's independence from any spiritual authority. The former, mentioned in Book I of the Monarchia, indicates "an alignment of the effects towards the cause ratione finis", while the latter, mentioned in Book III of the same text, "shows that the emperor's authority depends directly on God" (p. 383). It is in the same Book I that Dante cites the Book of Causes in order to the provide a metaphysical proof that the emperor can be considered a first cause that acts in the realm of time. As such, the monarchy, as an autonomous political institution, orders all the levels of reality to the ultimate end and "assures the causal connection between intermediaries and effects" (p. 384).

Sokrates-Athanasios Kiosoglou considerably enriches the list of propositions from the Elements of Theology in Ficino's Commentary on Philebus providing evidence for either (shorter / longer) literal citations or freely adapted paraphrases from propositions 8, 9, 21, 26, 27, 31, 35, 43, 80, 134, 143, 186, 191, 199. In all these cases, Moerbeke's Latin translation seems to have been used and preferred to Proclus' Greek text. In a pioneering study, C. Steel observed the presence of only propositions $1-4,5,20$ in chapter IV, prop. 13 in chapter $V$ and prop. 12 in chapters $\mathrm{V}$ and $\mathrm{xxx}$ of Ficino's Commentary on Philebus.

Kiosoglou deliberately avoids discussing the question of Ficino's translation of Elements of Theology. In a letter to Poliziano from 1474, Ficino claims that he translated the Elements of Theology and the Elements of Physics, yet in the second catalogue sent to Prenninger in 1489 , he does not mention them among his translations and adds that he read them in the extant Latin translations (despite his knowledge of Greek). This topic has been recently examined by D. Robichaud, and Kiosoglou's contribution brings forth overlooked proofs about Ficino's knowledge and use of the Elements of Theology.

Kiosoglou endorses Steel's thesis that these citations from Proclus' Elements of Theology are not simple adornments, but have a doctrinal weight articu- 
lating from within Ficino's own "conceptualization of felicity, and, by extension, of pleasure" (p. 398), the goal that we all try to reach. Moreover, Kiosoglou concludes: "In grounding the whole commentary on Proclus' axiomatic formulations (and not so much as one might expect on Dionysius' attractive, but suspicion-arousing, eloquence), Ficino provided his audience with a seemingly unquestionable and solid system of thought that, despite its pagan character, could easily be presented as the basis of a Christian worldview" (p. 402).

Jean-Pierre Rothschild focuses on the hitherto partially unedited glosses and commentaries of Hillel of Verona, the first translator of the Book of Causes into Hebrew. An edition and French translation are provided in the appendix of the article.

Rothschild firstly notes the remarkable interest for the Book of Causes between the end of the 13th and the end of the 15th century: it was translated five times after 1272, four times from Latin, and once from Arabic. However, that diffusion is limited to a restrained, privileged circle of learned scholars (often from the same intellectual lineage) interested in the most influential texts of the Western tradition.

Hillel of Verona's translation of the Book of Causes and original commentary (assuming, with a degree of probability, that there is one and the same author) are preserved in a unique manuscript at the Bodleian in Oxford. Rothschild reassesses the chronology of this translation and places it after 1272, showing that Hillel knew (at least partially) Aquinas'De ente et essentia and commentary on the Liber de causis, as well as the Moerbeke's Latin translation of Aristotle's Metaphysics, and probably even Giles of Rome's commentary on the Liber de causis. Hillel's is the only Hebrew running commentary on the Book of Causes. Juda Romano's partial translation of Aquinas' Exposition on the Book of Causes, or Moïse b. Sabbataï's sporadic glosses in the margins of Juda's translation do not have the same importance in this respect. Moreover, Hillel is the first (and probably the only) author who connects the Book of Causes to the Book of Principles by al-Fārābī (not known to Latin authors), to whom he also attributes (like other Latin authors) the secondary propositions of the Book of Causes.

Hillel's commentary rejects, at times, the doctrines of the Book of Causes as "contrary to faith", but, as Rothschild observes, that may indicate the influence from Thomas Aquinas' interpretation (for example, in prop. $\mathrm{x}(\mathrm{XI})$ ). The possible influence of Maimonides' theory of the divine names can be observed 
in Hillel's commentaries on prop. XVI(XVII) and XVII(XVIII). Another remarkable aspect of Hillel's commentary is his criticism of Neoplatonic principles from the point of view of medieval medicine: Hillel was also a trained physician. Rothschild convincingly argues that "ce traducteur-critique, encore une fois, tient dans l' histoire du Liber de causis une position singulière" (p. 427).

Saverio Campanini endorses Rothschild's remarks about the vast diffusion of the Book of Causes in Jewish Medieval thought, from (probably) lost translations to the "endless field of tacit" references. Campanini focuses on Kabbalistic literature. In some older sources, one finds the "classical" attribution to Aristotle and the title Book of Causes: Moshe Botarel (15th c.) mentions this reference in the Kevod ha-Shem attributed to El 'azar ha-Qallir (6th-7th c.). A more subtle and diffused influence of the Book of Causes, yet with an attribution to Plato, is to be found in Azri'el of Gerona's Derek ha-emunah we-derek ha-kefirah (12th-13th c.). These are some of the oldest references to the Book of Causes outside the written tradition in Arabic.

The best-known reference to the Book of Causes is the passage quoted by Abraham Abulafia (second half of the 13th c.) in his Imre shefer where he explicitly cites prop. $\mathrm{v}(\mathrm{VI})$ of "the Book of the Highest Substances" written by Plato. None of the known Hebrew translations of the Book of Causes could have been the source for Abulafia, although he was a pupil of Hillel (which might explain the reference to Plato, and also to al-Fārābī). The reference and citation are found in the 16th century Sha'ar ha-chesheq by Jochanan Alemanno, a large commentary on the Song of Songs. Campanini argues that Jochanan Alemanno quotes Liber de causis "repeatedly in his unpublished works and notebooks" and was aware of its Neoplatonic metaphysical background, referring explicitly to Proclus (p. 461). One can conclude that he was aware of the Latin tradition originated in Aquinas' commentary. From Alemanno, the reference to "the Book of the Highest Substances" passed into Isaac Abravanel's commentary on the book of Exodus $(40,34)$ written in Venice around 1506; and from Abravanel into Joseph Del Medigo's Sefer Novelot Chokmah, printed in Basel in 1631. Joseph Del Medigo stressed the similarities between the doctrines of the De causis (attributed by Plato) with Proclus, Plotinus, Al-Ghazālī, the Kabbalists, the Bible and the Jewish exegetes.

Campanini's final remarks describe the role of the Book of Causes for Kabbalists: "Kabbalah does not need the Liber de causis, and not even negative theology, but is ready to use it for apologetic purposes, to defend ad extra its ineffable contents" (p. 474). 
This volume does not aim to exhaust the question of the diffusion of Proclus' Elements of Theology: it is not a compendium and it should not be considered as such. Its main goal is to gather studies that deepen questions that have been freely chosen by each contributor. However, some common interests can be identified within each of the five sections.

The studies of the first section isolate themes and citations (explicit and implicit) attesting to the diffusion of Proclus in Byzantium, and address some major questions about the authenticity of many of these works. This effort is also carried on with the contribution on "Caucasian philosophy" inasmuch as the first Georgian monk, Ioane Petritsi, who translated and commented the Elements of Theology, was probably a pupil of Michael Psellos and John Italos. The section dedicated to the lands of Islam focuses mainly on the 9th-century historical and cultural context that prepared and made possible the composition of the Book of Causes. The contributions study the circle of al-Kindī, where both Plotinus and Proclus were translated and adapted to a monotheistic environment within the same "Aristotelised" intellectual milieu. In a remarkable paper entitled "Aristotélisation de la gnoséologie néoplatonicienne dans le Kaläm $f i$ mahd al-khair", presented on April 16, 2016, Marc Geoffroy analysed in great details the transformation and translation of proposition 123 from the Elements of Theology into chapter $\mathrm{v}(\mathrm{VI})$ of the Book of Causes, underlying some of the previously overlooked sources for the Book of Causes, such as Aristotle's De anima and De sensu et sensato, and the vocabulary borrowed from the Qur'àn. The written text of this paper could not be found on Marc Geoffroy's computer. Fortunately, there is an audio-recording of his paper, in French, uploaded and accessible at the following address: https://www.neoplat.eu/media/. The section dedicated to the Latin West analyses mainly the reception of the Book of Causes both in Latin and in vernacular, but also the tacit citations of the Elements of Theology in Ficino's Commentary on the Philebus. The reception of the Book of Causes in the Jewish medieval thought (in both philosophical and Kabbalistic texts) depends mostly—yet not exclusively! —on the Latin tradition.

Cluj-Napoca

8 May 2020 